\title{
Pengaruh Model Pembelajaran Value Clarification Technique Berbasis Penilaian Proyek Terhadap Kompetensi Pengetahuan PKn
}

\author{
Ni Luh Putu Dima Septiari ${ }^{1}$, I.G.A. Agung Sri Asri ${ }^{2}$, Ni Wayan Suniasih ${ }^{3}$ \\ Jurusan Pendidikan Guru Sekolah Dasar, FIP \\ Universitas Pendidikan Ganesha \\ Singaraja, Indonesia \\ e-mail: dimaseptiari@gmail.com ${ }^{1}$, igaagungsriasri@undiksha.ac.id², \\ niwayan.suniasih@undiksha.ac.id
}

\begin{abstract}
Abstrak
Penelitian ini bertujuan untuk mengetahui perbedaan yang signifikan kompetensi pengetahuan PKn antara siswa yang dibelajarkan melalui model pembelajaran Value Clarification Technique berbasis penilaian proyek dengan siswa yang dibelajarkan melalui pembelajaran konvensional pada siswa kelas IV SD Gugus Letda Made Putra Tahun Pelajaran 2017/2018. Penelitian ini merupakan penelitian eksperimen semu dengan rancangan nonequivalent control group desain. Populasi penelitian ini adalah seluruh siswa kelas IV SD di Gugus Letda Made Putra yang terdiri dari 393 siswa. Sampel pada penelitian ini adalah sebanyak 75 siswa, penentuan kelompok eksperimen dan kelompok kontrol menggunakan teknik random sampling. Data kompetensi pengetahuan PKn dikumpulkan dengan instrument berupa tes objektif pilihan ganda biasa. Data dianalisis menggunakan uji-t dengan rumus polled varians. Berdasarkan hasil penelitian ini disarankan agar penelitian ini dapat dijadikan sebagai kajian yang relevan khususnya sebagai penunjang bagi peneliti dengan kajian yang lebih luas dan memperdalam teori mengenai model pembelajaran Value Clarification Technique berbasis penilaian proyek.
\end{abstract}

Kata Kunci: Value Clarification Technique, penilaian proyek, kompetensi pengetahuan PKn.

\begin{abstract}
This research aims to know the significant difference between the PKn knowledge competence of students through Values Clarification Technique model based assessment project with students that learned through conventional learning on students of $4^{\text {th }}$ grader in $S D$ Gugus Letda Made Putra year 2017/2018. The type of this research is experimental research with nonequivalent control group design. This research population is all $4^{\text {th }}$ grade student in $S D$ Gugus Letda Made Putra which there is 393 students. The samples in this research is 75 students, the determination group of experimental and control group using random sampling technique. In collecting data with PKn knowledge competence instrument in the form of multiple choice objective test. Therefore it can be concluded that there is Values Clarification Technique model based assessment project against PKn knowledge competencies on $4^{\text {th }}$ grade student in SD Gugus Letda Made Putra year 2017/2018. Based on the results of this study suggested that this research can be used as a relevant study, especially as a supporter for researchers with a broader study and deepen the theory of learning model Value Clarification Technique based on project appraisal.
\end{abstract}

Keywords: Value Clarification Technique, assessment project, PKn knowledge competence 


\section{Pendahuluan}

Perkembangan ilmu pengetahuan dan teknologi sekarang ini sangat menuntut adanya inovasi baru yang dapat menimbulkan suatu perubahan. Perubahan tersebut dapat tercapai apabila memiliki sumber daya manusia yang berkualitas dan memiliki kemampuan berpikir kreatif. Salah satunya melalui pendidikan, melalui pendidikan diharapkan dapat menghasilkan sumber daya manusia yang berkualitas serta memiliki kemampuan berpikir kreatif. Pada UU Sisdiknas No. 20 Tahun 2003 dipaparkan bahwa "Pendidikan Nasional bertujuan untuk berkembangnya potensi peserta didik agar menjadi manusia yang beriman dan bertakwa kepada Tuhan Yang Maha Esa, berakhlak mulia, sehat, berilmu, cakap, kreatif, mandiri dan menjadi warga negara yang demokratis, serta bertanggung jawab". "Pendidikan merupakan kumpulan dari semua proses yang memungkinkan seseorang mampu mengembangkan seluruh kemampuan (potensi) yang dimilikinya, sikap-sikap dan bentuk-bentuk perilaku yang bernilai positif di masyarakat" (Sukardjo \& Komarudin, 2013:9). "Pendidikan bermakna sebagai usaha manusia untuk menumbuhkan dan mengembangkan potensi-potensi pembawaan, baik jasmani maupun rohani sesuai dengan nilai-nilai yang ada dalam masyarakat dan kebudayaan" (Anwar, 2015:19). Jadi, pendidikan merupakan proses yang dilakukan seseorang untuk mengembangkan potensi yang dimilikinya agar menjadi manusia yang beriman dan bertakwa kepada Tuhan Yang Maha Esa, berakhlak mulia, sehat, berilmu, cakap, kreatif, mandiri dan menjadi warga negara yang demokratis, serta bertanggung jawab yang dapat bernilai positif di masyarakat.

Seiring dengan perkembangan ilmu pengetahuan dan teknologi, secara otomatis pola pikir masyarakat berkembang dalam setiap aspek. Hal ini sangat berpengaruh khususnya dalam dunia pendidikan yang menuntut adanya inovasi baru yang dapat menimbulkan suatu perubahan. Dimana di dalam dunia pendidikan, guru memegang peranan utama dan bertanggung jawab menyebarluaskan gagasan baru terhadap siswa melalui proses pengajaran di dalam kelas, yang memegang peranan penting dalam membantu peserta didik untuk membangun sikap positif dalam belajar, membangkitkan rasa ingin tahu, mendorong kemandirian, serta menciptakan kondisi-kondisi untuk sukses dalam belajar. Ada beberapa komponen yang terlibat di dalam proses belajar, seperti pendidik atau guru, media dan strategi pembelajaran, kurikulum, dan sumber belajar. Dari proses belajar tersebut lahir kata pembelajaran yang dimana pembelajaran adalah usaha sadar yang dilakukan oleh guru atau pendidik untuk membuat siswa atau peserta didik belajar (mengubah tingkah laku untuk mendapatkan kemampuan baru) yang berisi suatu sistem atau rancangan untuk mencapai suatu tujuan (Khanifatul, 2013:14).

Guru diharapkan bisa menyiapkan dan membuka diri terhadap beberapa kemungkinan terjadinya perubahan Kurikulum. Kurikulum adalah seperangkat rencana dan pengaturan mengenai tujuan, isi, dan bahan pelajaran serta cara yang digunakan sebagai pedoman penyelenggaraan kegiatan pembelajaran untuk mencapai tujuan pendidikan tertentu (Kurniasih dan Sani, 2014:2). Pembaharuan kurikulum terus dilakukan untuk menyempurnakan kurikulum yang telah dirintis sebelumnya, seperti diterapkan Kurikulum Berbasis Kompetensi (KBK) pada tahun 2004 kemudian diteruskan dengan kurikulum 2006 (KTSP) dan pada saat ini telah diberlakukan kurikulum baru yaitu Kurikulum 2013. Dalam proses pembelajaran Kurikulum 2013, seluruh muatan materi pelajaran akan dipadukan secara integratif dalam satu tema menjadi satu kesatuan yang disebut pembelajaran tematik.

Pada pembelajaran tematik, mata pelajaran yang dipadukan secara integratif dalam satu tema salah satunya adalah PKn (Pendidikan Kewarganegaraan). Mata pelajaran PKn bertujuan untuk membentuk manusia Indonesia seutuhnya yang berlandaskan pada Pancasila, undangundang dan norma-norma yang berlaku di masyarakat (Susanto, 2013:224). Di sekolah dasar mata pelajaran PKn diharapkan agar siswa sejak dini dapat memahami dan mampu melaksanakan hak-hak dan kewajibannya untuk menjadi warga negara Indonesia yang cerdas, terampil, dan berkarakter yang diamanatkan oleh Pancasila dan UUD 1945, dan memahami nilai-nilai kedisiplinan, kejujuran, serta sikap yang baik terhadap sesamanya, lawan jenisnya, maupun terhadap orang yang lebih tua. Namun sangat disayangkan bahwa dalam aplikasinya, mata pelajaran PKn ini kurang banyak diminati peserta didik karena peserta didik masih terpaku pada menghafal yang mengakibatkan peserta didik kurang memahami materi yang disampaikan. Bahkan pada era globalisasi saat ini banyak terjadi tawuran di kalangan anak sekolah dasar, dimana pada bangku sekolah dasar peserta didik seharusnya belajar sejak dini untuk saling menghargai antar sesama makhluk ciptaan Tuhan, memahami nilai-nilai kedisiplinan, dan kejujuran. Untuk mencapai hal tersebut, seorang guru dapat menanamkan 
pengetahuan konsep dasar tentang hak dan kewajiban, hak asasi, peraturan-peraturan, perilaku, dan sikap moral secara benar, terukur dan terencana. Mata pelajaran PKn selain mengharapkan siswa agar dapat memahami pengetahuan yang diperoleh dari proses pembelajaran siswa juga diharapkan mampu melaksanakan ataupun menerapkan pengetahuannya.

Sesuai dengan kondisi yang dialami dalam mata pelajaran PKn maka diperlukan upaya menemukan model pembelajaran dengan menyampaikan materi pelajaran secara tepat serta memenuhi muatan tatanan nilai agar dapat diinternalisasikan pada diri siswa serta mengimplementasikan hakikat pendidikan nilai dalam kehidupan sehari-hari. Model pembelajaran VCT dapat dijadikan model pembelajaran alternatif dalam pembelajaran PKn karena mata pelajaran Pendidikan Kewarganegaraan menekankan pembelajaran pada ranah sikap yaitu wahana penanaman nilai, moral dan norma-norma seperti rasa sosial serta nasionalisme.

Model pembelajaran Value Clarification Technique atau sering disingkat VCT merupakan teknik pengajaran untuk membantu siswa dalam mencari dan menentukan suatu nilai yang dianggap baik dalam menghadapi suatu persoalan melalui proses menganalisis nilai yang sudah ada dan tertanam dalam diri siswa (Taniredja, dkk 2015:87). VCT juga merupakan pendekatan pendidikan dimana peserta didik dilatih untuk menemukan, memilih, menganalisis, memutuskan mengambil sikap sendiri nilai-nilai hidup yang ingin diperjuangkannya (Adisusilo, 2012:141). Putra (2014) "model pembelajaran VCT merupakan model inovatif yang menekankan nilai sosial, budaya, personal dan masyarakat". Dipilihnya model pembelajaran VCT karena model pembelajaran ini bertujuan melatih siswa dalam menerima - menilai nilai dirinya dan posisi nilai orang lain, menerima serta mengambil keputusan terhadap suatu persoalan yang berhubungan dengan pergaulannya dan kehidupan sehari-hari.

Pendidikan Kewarganegaraan selain identik pada penilaian sikap, juga dapat dilakukan penilaian proses yaitu dengan penilaian proyek. Penilaian proyek merupakan kegiatan penilaian terhadap suatu tugas yang harus diselesaikan dalam periode/waktu tertentu (Uno dan Koni, 2012:24). Tugas tersebut mengandung investigasi sejak dari perencanaan, pengumpulan data, pengorganisasian, pengolahan, dan penyajian data. (Suastini, 2015) "Kelebihan penilaian proyek adalah meningkatkan motivasi, meningkatkan kemampuan pemecahan masalah, meningkatkan kolaborasi, meningkatkan keterampilan mengelola sumber, dan meningkatkan skill". Dengan demikian diharapkan siswa mampu menyusun, mengumpulkan, menganalisis serta melaporkan hasil dari investigasi. Proyek yang dilakukan peserta didik harus merupakan hasil karyanya sehingga pemahaman dan pengetahuan siswa terhadap apa yang dipelajari dapat meningkat terutama dalam mata pelajaran Pendidikan Kewarganegaraan (PKn).

Menurut Harris (2013) Respon siswa terhadap penerapan model pembelajaran VCT siswa sangat senang, tertarik, menantang, memperoleh wawasan lebih luas, melalui model pembelajaran VCT karena siswa lebih aktif dalam pembelajaran, materi yang disampaikan mudah dipahami, siswa dapat bekerja sama dengan baik dalam kelompok.

Sri Rejeki (2015) menyatakan bahwa Penggunaan Model Pembelajaran VCT untuk pembelajaran PKn dalam penelitian ini dapat membantu siswa dalam meningkatkan civic disposition (karakter kewarganegaraan) sehingga dapat menjadi warga negara yang cerdas, terampil dan berkarakter yang kuat sesuai dengan peradapan bangsa. Hal ini sejalan dengan penelitian yang dilakukan Sariani (2016) yang menyatakan hal serupa dimana terdapat perbedaan yang signifikan sikap sosial dan hasil belajar PKn secara simultan antara siswa yang mengikuti pembelajaran dengan pembelajaran teknik klarifikasi nilai (TKN) melalui bermain peran dengan siswa yang mengikuti pembelajaran konvensional.

Berdasarkan uraian tersebut, menunjukkan bahwa pemilihan model dalam proses pembelajaran sangatlah penting dilakukan oleh guru untuk membelajarkan peserta didik di dalam kelas khususnya mata pelajaran PKn. Seberapa jauh model dapat berperan dalam mengoptimalkan kompetensi pengetahuan siswa, maka diadakan penelitian yang berjudul "Pengaruh Model Pembelajaran Value Clarification Technique Berbasis Penilaian Proyek terhadap Kompetensi Pengetahuan PKn Siswa Kelas IV SD Gugus Letda Made Putra Tahun Pelajaran 2017/2018".

\section{Metode}

Jenis penelitian menggunakan desain eksperimental yaitu quasi eksperiment (Eksperimen Semu). Desain penelitian ini mempunyai kelompok kontrol, tetapi tidak dapat berfungsi sepenuhnya untuk mengontrol variabel-variabel luar yang mempengaruhi 
pelaksanaan eksperimen (Sugiyono, 2016:114). Bentuk desain eksperimen yang digunakan adalah Nonequivalent Control Group Design.

Dalam desain ini, ada dua kelompok subjek yakni satu kelompok mendapat perlakuan (eksperimen) dan satu kelompok sebagai kelompok kontrol. Kelompok eksperimen mendapatkan perlakuan khusus dengan menerapkan model pembelajaran Value Clarification Technique berbasis penilaian proyek sedangkan untuk kelompok kontrol tidak mendapatkan perlakuan. Kedua kelompok memperoleh pretest dan posttest.

Populasi dalam penelitian ini adalah seluruh siswa kelas IV SD Gugus Letda Made Putra tahun pelajaran 2017/2018 yang berjumlah 393 siswa. Teknik pengambilan sampel pada penelitian ini dilakukan dengan random sampling, yakni yang dirandom adalah kelas. "Random sampling merupakan cara pengambilan sampel dengan memberikan kesempatan yang sama kepada anggota populasi untuk diambil menjadi anggota sampel" (Agung, 2014:71). Dengan demikian, dalam penelitian ini setiap anggota populasi yang ada di kelas IV SD Negeri Gugus Letda Made Putra memperoleh hak yang sama dan mendapat kesempatan dipilih menjadi sampel. Sampel yang digunakan dalam penelitian ini yaitu kelas IVB SD N 2 Dangin Puri dan kelas IV SD N 1 Tonja. Untuk menentukan kelompok eksperimen dan kelompok kontrol sampel diuji terlebih dahulu kesetaraannya, Kesetaraan sampel diuji dengan rumus uji-t yakni polled varians bila $\mathrm{n}_{1} \neq \mathrm{n}_{2}$ dan varian homogen. Berikut rumus uji-t polled varians.

$$
t=\frac{\bar{X}_{1}-\bar{X}_{2}}{\sqrt{\frac{\left(n_{1}-1\right) s_{1}^{2}+\left(n_{2}-1\right) s_{2}^{2}}{n_{1}+n_{2}-2}\left(\frac{1}{n_{1}}+\frac{1}{n_{2}}\right)}}
$$

(Sugiyono, 2016:273)

Dengan kriteria harga $t_{\text {hitung }} \leq$ harga $t_{\text {tabel }}$, maka $\mathrm{H}_{0}$ diterima dan $\mathrm{H}_{\mathrm{a}}$ ditolak, sehingga kelompok dinyatakan setara dan bila harga $t_{\text {hitung }}>$ harga $\mathrm{t}_{\text {tabel }}$ maka $\mathrm{H}_{0}$ ditolak dan $\mathrm{H}_{\mathrm{a}}$ diterima, sehingga kelompok dinyatakan tidak setara. Pada taraf signifikansi $5 \%$ dengan $d k=n_{1}+n_{2}-2$. Data nilai kedua kelompok sampel berdistribusi normal dan homogen dilanjutkan dengan melakukan uji kesetaraan dengan uji-t. Berikut hasil analisis uji kesetaraan dengan uji-t rumus polled varian. Pengujian statistik kesetaraan sampel menyatakan kedua kelompok sampel setara dengan perolehan $t_{\text {hitung }}=0,104<\mathrm{t}_{\text {tabel }}=2,000$. Selanjutnya dilakukan pengundian untuk menentukan kelompok eksperimen dan kelompok kontrol. Berdasarkan pengundian yang telah dilakukan, didapat kelas IVB SD N 2 Dangin Puri sebagai kelompok eksperimen dan SD N 1 Tonja sebagai kelompok kontrol.

Metode pengumpulan data dibedakan menjadi 2 (dua) teknik yaitu dengan teknik tes dan teknik non tes. Pada penelitian ini, data kompetensi pengetahuan PKn dikumpulkan dengan menggunakan tes objektif dalam bentuk pilihan ganda (Multiple Choice). Menurut Agung (2011:34) butir soal pilihan ganda merupakan suatu butir soal yang alternatif jawabannya lebih dari dua. Pada umumnya alternatif jawaban berkisar antara 4 atau 5 option. Pada tes objektif maka hanya ada dua kemungkinan jawaban, yaitu betul dan salah (Sudijono, 2013: 185). Setiap butir soal yang dijawab dengan benar diberikan skor 1 (satu) dan untuk setiap butir soal yang dijawab salah diberikan skor 0 (nol).

Kegiatan pengumpulan data kompetensi pengetahuan PKn dikumpulkan dengan tes kompetensi pengetahuan PKn yang dilaksanakan pada siswa kelas IV SD di Gugus Letda Made Putra yang menjadi anggota sampel. Menurut Yusuf (2015) tes merupakan suatu prosedur yang spesifik dan sistematis untuk mengukur tingkah laku seseorang; atau suatu pengukuran yang bersifat objektif mengenai tingkah laku seseorang. Tingkah laku tersebut dapat digambarkan dengan bantuan angka, skala, atau dengan sistem kategori.

Untuk mengetahui kompetensi pengetahuan PKn siswa yang diperoleh dari tes dapat diketahui dengan rumus sebagai berikut.

$$
\mathrm{N}=\frac{\text { skoryang diperoleh }}{\text { skormaksimalideal }} \times 100
$$

(Sudijono, 2013:318)

Pengujian instrumen dilakukan untuk mendapatkan gambaran secara empirik mengenai kelayakan suatu instrumen yang akan digunakan. Untuk menguji kelayakan suatu instrumen maka dilakukan pengujian instrumen yaitu dengan 1) uji validitas, instrumen evaluasi dipersyaratkan valid agar hasil yang diperoleh dari kegiatan evaluasi valid. Instrumen yang valid berarti alat ukur yang digunakan untuk mendapatkan data (mengukur) itu valid. Menurut 
Sugiyono (2016:173) valid berarti instrumen tersebut dapat digunakan untuk mengukur apa yang seharusnya diukur. Untuk mengukur validitas item atau butir tes kompetensi pengetahuan PKn dalam bentuk tes objektif pilihan ganda biasa digunakan rumus korelasi point biserial.

$$
y_{p b i}=\frac{M_{p}-M_{t}}{S_{t}} \sqrt{\frac{p}{q}}
$$

(Arikunto, 2015:93)

Hasil uji valliditas mendapatkan 35 butir soal yang valid dan 15 butir soal yang tidak valid. 2) uji daya beda, Daya beda butir tes adalah kemampuan butir tes tersebut membedakan antara testee kelompok atas (pintar) dan testee kelompok bawah (lemah) Agung (2011:64). Untuk menentukan kelompok atas dan kelompok bawah dilakukan dengan cara menyusun secara urut dimulai dari testee yang memperoleh skor tertinggi sampai dengan testee yang memperoleh skor terendah. Karena jumlah siswa yang ikut serta dalam uji coba instrumen adalah 32 orang. Dimana jumlah testee kurang dari 100 orang (kelompok kecil), maka kelompok testee tersebut dibagi dua sama besar, 50\% kelompok atas dan 50\% kelompok bawah (Arikunto, 2015:227). Berikut rumus yang dipergunakan untuk menentukan daya pembeda suatu soal.

$$
D=\frac{B_{A}}{J_{A}}-\frac{B_{B}}{J_{B}}=P_{A}-P_{B}
$$

(Arikunto, 2015:228)

Hasil uji daya beda mendapatkan 1 butir soal pada kriteria jelek, 17 buti soal pada kriteria cukup, 15 butir soal pada kriteria baik dan 2 butir soal pada kriteria baik sekali. Dengan demikian butir soal yang dipergunakan dalam menyusun instrumen berjumlah 34 soal. 3) uji indeks kesukaran, Menurut Agung (2011:63) tingkat kesukaran tes adalah bilangan yang menunjukkan proporsi peserta ujian (testee) yang dapat menjawab betul butir soal. Bilangan yang menunjukkan sukar dan mudahnya suatu soal disebut indeks kesukaran. Indeks kesukaran berkisar antara 0,00 sampai dengan 1,00 yang dapat menunjukkan taraf kesukaran soal. Soal dengan indeks kesukaran 0,00 menunjukkan bahwa butir soal tersebut terlalu sukar dan sebaliknya jika indeks kesukaran 1,00 menunjukkan bahwa butir soal tersebut terlalu mudah. Berikut rumus uji indeks kesukaran butir tes:

$$
P=\frac{B}{J S}
$$

(Arikunto, 2015:223)

Hasil uji indeks kesukaran butir tes didapat 4 butir soal pada kriteria sukar, 21 butir soal pada kriteria sedang, 9 butir soal pada kriteria mudah. Berdasarkan hasil perhitungan, maka diketahui indeks kesukaran perangkat tes adalah 0,61 sehingga indeks kesukaran perangkat tes termasuk dalam kriteria sedang. 4) uji reliabilitas, Penelitian yang reliabel memilki hasil yang sama dalam waktu yang berbeda. Instrumen yang reliabel merupakan instrumen yang bila digunakan beberapa kali untuk mengukur objek yang sama maka akan menghasilkan data yang sama. Menurut Agung (2011:57) suatu tes dikatakan memiliki reliabilitas tinggi apabila tes tersebut dapat memberikan hasil yang tepat (ajeg). Uji reliabilitas tes yang digunakan yaitu dengan rumus Kuder Richardson $\left(\mathrm{KR}_{20}\right)$.

$$
r_{11}=\left(\frac{n}{n-1}\right)\left(\frac{S_{t}^{2}-\sum p_{i} q_{i}}{S_{t}^{2}}\right)
$$

(Sudijono, 2013:252)

Berdasarkan hasil perhitungan dari 34 butir soal yang dinyatakan valid maka diperoleh $r_{11}=0,903$. Jika diinterpretasikan maka soal tes pilihan ganda pada penelitian ini tergolong reliabilitas sangat tinggi.

Analisis data dalam penelitian kuantitatif merupakan kegiatan setelah data dari seluruh responden atau sumber data lain terkumpul. Data hasil pretest dan posttest yang terkumpul dari 
kelompok eksperimen dan kelompok kontrol dianalisis terlebih dahulu dengan mencari gain score yang dinormalisasi. Adapun rumus yang digunakan adalah sebagai berikut.

$$
\mathrm{GSn}=\frac{\text { Gain } \text { Skor }}{\text { Skormax } \text { ideal }- \text { skor pretest }}
$$

(Dantes, 2017:126)

Menurut Sugiyono (2016) statistik deskriptif adalah statistik yang digunakan untuk menganalisis data dengan cara mendeskripsikan atau menggambarkan data yang telah terkumpul sebagaimana adanya tanpa bermaksud membuat kesimpulan yang berlaku untuk umum atau generalisasi. Statistik deskriptif dipergunakan saat mendeskripikan data sampel, yang berarti statistik deskriptif digunakan untuk mengetahui kompetensi pengetahuan PKn setelah diberikan perlakuan melalui model pembelajaran Value Clarification Technique berbasis Penilaian Proyek serta kompetensi pengetahuan PKn setelah dibelajarkan melalui pembelajaran konvensional. Penyajian data yang digunakan dalam statistik deskriptif ini adalah melalui Mean (menghitung rata-rata) dan standar deviasi dan varians. Setelah mendapatkan data mengenai rata-rata nilai siswa, selanjutnya data tersebut dibandingkan dengan tabel kriteria penggologan gain skor ternormalisasi. Pembelajaran dinyatakan berhasil apabila perolehan rata-rata gain skor kompetensi pengetahuan PKn mencapai predikat minimal sedang.

Statistik Inferensial merupakan bidang ilmu statistika yang mempelajari tentang tata cara penarikan kesimpulan-kesimpulan mengenai keadaan populasi (Agung, 2016:3). Statistik inferensial dipergunakan untuk mengetahui perbedaan kompetensi pengetahuan PKn antara kelompok siswa yang dibelajarkan melalui model pembelajaran Value Clarification Technique berbasis Penilaian Proyek dengan kelompok siswa yang dibelajarkan melalui pembelajaran konvensional. Analisis data menggunakan uji statistik yaitu dengan uji-t. Rumus uji-t dengan rumus polled varians digunakan bila jumlah anggota sampel $n_{1} \neq n_{2}$ dan varians homogen. Berikut rumus uji-t dengan rumus polled varians.

$$
t=\frac{\bar{X}_{1}-\bar{X}_{2}}{\sqrt{\frac{\left(n_{1}-1\right) s_{1}^{2}+\left(n_{2}-1\right) s_{2}^{2}}{n_{1}+n_{2}-2}\left(\frac{1}{n_{1}}+\frac{1}{n_{2}}\right)}}
$$

(Sugiyono, 2016:273)

Sebelum dilakukan uji-t terlebih dahulu diuji prasyarat analisis. Pengujian normalitas sebaran data dengan menggunakan metode kolmogorov-smirnov dan homogenitas varians data dengan menggunakan uji-F. Berikut rumus untuk mencari homogenitas varians dengan menggunakan uji Fisher (F).

$$
F=\frac{\text { Varians yang lebih besar }}{\text { Varians yang lebih kecil }}
$$

(Agung, 2016:76)

Sesuai dengan hipotesis penelitian yang telah diajukan, maka hipotesis yang diuji dalam penelitian ini adalah:

$\mathrm{H}_{0} \quad$ : Tidak terdapat perbedaan yang signifikan kompetensi pengetahuan PKn antara kelompok siswa yang dibelajarkan melalui model pembelajaran Value Clarification Technique berbasis penilaian proyek dengan kelompok siswa yang dibelajarkan melalui pembelajaran Konvensional pada siswa kelas IV SD Negeri di Gugus Letda Made Putra Tahun Pelajaran 2017/2018.

Hipotesis statistik yang diuji dalam penelitian ini adalah:

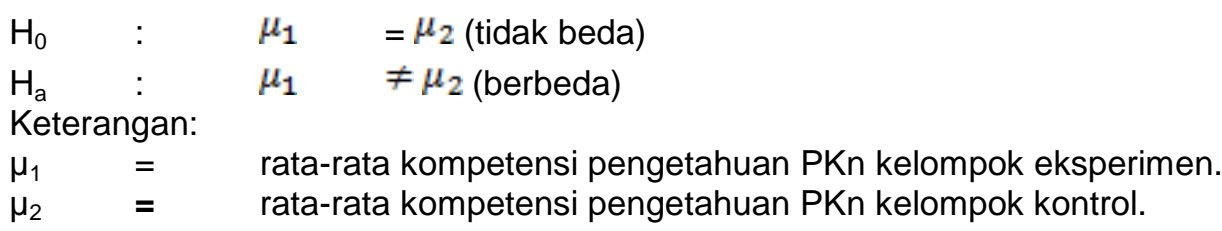




\section{Hasil dan Pembahasan}

Deskripsi data dalam penelitian ini memaparkan rata-rata (mean), standar deviasi, dan varians dari data gain skor kompetensi pengetahuan PKn pada kelompok eksperimen dan kelompok kontrol. Data yang diperoleh dalam penelitian ini dikelompokkan menjadi dua yaitu, 1) Kelompok eksperimen dalam penelitian ini adalah kelas IVB SD N 2 Dangin Puri berjumlah 32 orang. Berdasarkan perhitungan, kompetensi pengetahuan PKn pada kelompok eksperimen diperoleh rata-rata gain skor ternormalisasi yaitu 0,487. Rata-rata gain skor ternormalisasi kompetensi pengetahuan PKn kemudian dikonversikan pada tabel pengkategorian kompetensi pengetahuan PKn kelompok eksperimen pada PAN skala lima, sehingga dapat diketahui kompetensi pengetahuan PKn siswa kelompok eksperimen berada pada rentang 0,394 -0,580 dengan kategori cukup baik. Dari perhitungan standar deviasi dan varians diperoleh standar deviasi kelompok eksperimen adalah 0,185 dan varians 0,034. 2) Kelompok kontrol dalam penelitian ini adalah kelas IV SD N 1 Tonja berjumlah 43 orang. Berdasarkan perhitungan, kompetensi pengetahuan $\mathrm{PKn}$ pada kelompok kontrol diperoleh rata-rata gain skor ternormalisasi yaitu 0,327. Rata-rata gain skor ternormalisasi kompetensi pengetahuan PKn kemudian dikonversikan pada tabel pengkategorian kompetensi pengetahuan PKn kelompok kontrol pada PAN skala lima, sehingga dapat diketahui kompetensi pengetahuan PKn siswa kelompok kontrol berada pada rentang 0,245 - 0,409 dengan kategori cukup baik. Dari perhitungan standar deviasi dan varians diperoleh standar deviasi kelompok eksperimen adalah 0,163 dan varians 0,027 .

Berdasarkan hasil analisis data dengan menggunakan gain skor ternormalisasi diperoleh rata-rata gain skor ternormalisasi kompetensi pengetahuan PKn kelompok eksperimen yaitu 0,487 dan pada kelompok kontrol diperoleh rata-rata gain skor kompetensi pengetahuan PKn yaitu 0,327. Rata-rata gain skor ternormalisasi kompetensi pengetahuan PKn pada kelompok eksperimen dan kelompok kontrol setelah dikonversikan pada tabel pengkategorian PAN skala lima sama-sama berada pada kategori cukup baik. Walaupun sama-sama berada pada kategori cukup baik, hasil rentangan yang diperoleh pada setiap kelompok berbeda sehingga hanya berlaku pada kelompok yang bersangkutan dan tidak dapat dibandingkan dengan kelompok lain. Dilihat dari rata-rata gain skor kompetensi pengetahuan PKn pada kelompok eksperimen lebih dari kelompok kontrol $(M=0,487>M=0,327)$. Dari analisis diketahui bahwa sebaran data kompetensi pengetahuan PKn siswa berdistribusi normal dan memiliki varians homogen. Hasil analisis uji $t$ diperoleh $t_{\text {hitung }}=4,000$. Hasil tersebut kemudian dibandingkan dengan $t_{\text {tabel }}$ dengan $\mathrm{dk}=(32+43-2)=73$ pada taraf signifikansi $5 \%$ sehingga diperoleh $\mathrm{t}_{\text {tabel }}=2,000$.

Karena $t_{\text {hitung }}=4,000>t_{\text {tabel }}=2,000$, maka $\mathrm{H}_{0}$ ditolak dan $\mathrm{H}_{\mathrm{a}}$ diterima. Dengan demikian, dapat dinyatakan bahwa terdapat perbedaan yang signifikan kompetensi pengetahuan PKn antara kelompok siswa yang dibelajarkan melalui model pembelajaran Value Clarification Technique berbasis penilaian proyek dengan kelompok siswa yang dibelajarkan melalui pembelajaran konvensional pada siswa kelas IV SD Gugus Letda Made Putra tahun pelajaran 2017/2018, hal ini berarti terdapat pengaruh model pembelajaran Value Clarification Technique berbasis penilaian proyek terhadap kompetensi pengetahuan PKn siswa kelas IV SD Gugus Letda Made Putra tahun pelajaran 2017/2018.

Berdasarkan hasil temuan, dapat dinyatakan kedua kelompok sampel yang sebelumnya memiliki kemampuan setara, setelah diberikan perlakuan dengan model pembelajaran Value Clarification Technique berbasis penilaian proyek dan mengikuti pembelajaran dengan pembelajaran konvensional menunjukkan hasil yang berbeda. Hal ini dapat dilihat juga dari rata-rata siswa yang mengikuti pembelajaran dengan menerapkan model pembelajaran Value Clarification Technique berbasis penilaian proyek lebih tinggi daripada rata-rata siswa yang mengikuti pembelajaran konvensional. Perbedaan hasil kompetensi pengetahuan PKn di kelompok eksperimen dengan perolehan hasil rata-rata lebih tinggi dibandingkan dengan kelompok kontrol disebabkan karena pada kelompok eksperimen diberikan perlakuan berupa model pembelajaran Value Clarification Technique berbasis penilaian proyek dalam muatan materi PKn.

Pada kelompok eksperimen kegiatan pembelajaran dalam muatan materi PKn menerapkan model pembelajaran Value Clarification Technique berbasis penilaian proyek berjalan dengan optimal dan kondusif serta membuat siswa aktif dalam proses pembelajaran. $\mathrm{Hal}$ ini terlihat pada saat guru melontarkan stimulus berupa gambar yang berkaitan dengan pokok bahasan serta siswa terlihat sangat antusias dalam mengamati serta mengidentifikasi stimulus yang diberikan oleh guru. Pembelajaran dengan model pembelajaran Value Clarification Technique berbasis penilaian proyek didesain dengan membentuk kelompok kecil 
yang bertujuan agar siswa mampu bekerjasama dalam kelompok untuk memecahkan permasalahan dalam pembuatan suatu proyek yang berkaitan dengan pokok bahasan mengenai hak dan kewajiban tema 9 (Kayanya Negeriku) pada muatan materi PKn. Siswa di dalam kelompok mampu saling menghargai setiap perbedaan yang ada seperti perbedaan pendapat yang terjadi saat diskusi. Hal ini sejalan dengan pernyataan Adisusilo (2015:151) yang menyatakan bahwa model pembelajaran Value Clarification Technique dapat melatih siswa untuk berempati pada teman lain, berlatih untuk memecahkan persoalan serta melatih siswa untuk setuju ataupun menolak keputusan kelompok. Model pembelajaran Value Clarification Technique menekankan pada penanaman nilai dalam diri siswa sehingga dalam aktivitas sehari-hari nilai tersebut dapat menjadi suatu pedoman dalam bertingkah laku dan bersikap. Berbeda dengan kelompok kontrol yang menerapkan kegiatan pembelajaran konvensional. Kegiatan pembelajaran bersifat monoton, siswa kurang mampu mengaitkan antara materi pada muatan materi PKn dan siswa hanya terpaku pada hasil dari suatu kegiatan pembelajaran.

Hasil temuan pada penelitian ini memiliki persamaan dengan penelitian sebelumnya yang relevan, yakni penelitian dari Yuliasari (2013) yang menyatakan bahwa terdapat perbedaan signifikan hasil belajar PKn antara siswa yang mengikuti model pembelajaran VCT berbantuan media power point dan siswa yang mengikuti model pembelajaran konvensional. Penelitian lain yang memiliki kesamaan dengan penelitian ini adalah penelitian yang dilakukan oleh Maulida (2017) yang menyatakan bahwa terdapat perbedaan yang signifikan hasil belajar dalam mata pelajaran PKn antara kelompok siswa yang belajar dengan menggunakan model pembelajaran Value Clarification Technique dan kelompok siswa yang belajar dengan model pembelajaran konvensional pada siswa kelas $\mathrm{V}$.

\section{Simpulan dan Saran}

Berdasarkan hasil penelitian dan pembahasan maka dapat ditarik kesimpulan sebagai berikut. 1) Kompetensi pengetahuan PKn kelompok eksperimen yang dibelajarkan menggunakan model pembelajaran VCT berbasis penilaian proyek pada siswa kelas IV SD Gugus Letda Made Putra Tahun Pelajaran 2017/2018 diperoleh rata-rata gain skor ternormalisasi $^{M}=0,487$. Rata-rata gain skor ternormalisasi kompetensi pengetahuan PKn siswa kelompok eksperimen setelah dikonversikan pada tabel pengkategorian PAN skala lima berada pada rentang 0,394 - 0,580 dengan kategori cukup baik. 2) Kompetensi pengetahuan PKn kelompok siswa yang dibelajarkan menggunakan pembelajaran konvensional pada siswa kelas IV SD Gugus Letda Made Putra Tahun pelajaran 2017/2018 diperoleh rata-rata gain skor ternormalisasi $^{M}=0,327$. Rata-rata gain skor ternormalisasi kompetensi pengetahuan PKn siswa kelompok kontrol setelah dikonversikan pada tabel pengkategorian PAN skala lima berada pada rentang 0,245 - 0,409 dengan kategori cukup baik. 3) Terdapat perbedaan yang signifikan kompetensi pengetahuan PKn kelompok siswa yang dibelajarkan melalui model pembelajaran VCT berbasis penilaian proyek dengan kelompok siswa yang dibelajarkan melalui pembelajaran konvensional pada kelas IV SD Gugus Letda Made Putra Tahun Pelajaran 2017/2018. Terbukti dari hasil analisis uji-t diperoleh $t_{\text {hitung }}=4,000$ dan pada taraf signifikansi $5 \%$ dengan $d k={ }^{(32+43-2)}=73$ diperoleh $t_{\text {tabel }}=2,000$. Karena $t_{\text {hitung }}=4,000>t_{\text {tabel }}=$ 2,000. Rata-rata kompetensi pengetahuan PKn siswa kelompok eksperimen lebih dari rata-rata kompetensi pengetahuan PKn kelompok kontrol $\left.{ }^{M}=0,487>M=0,327\right)$. Sehingga dapat disimpulkan bahwa pembelajaran dengan model pembelaran VCT berbasis penilaian proyek berpengaruh terhadap kompetensi pengetahuan PKn siswa kelas IV SD Gugus Letda Made Putra Tahun Pelajaran 2017/2018. Sehingga dapat disimpulkan bahwa pembelajaran dengan model pembelaran Value Clarification Technique berbasis penilaian proyek berpengaruh terhadap kompetensi pengetahuan PKn siswa kelas IV SD Gugus Letda Made Putra Tahun Pelajaran 2017/2018. 


\section{Daftar Pustaka}

Adisusilo, Sutarjo. 2012. Pembelajaran Nilai Karakter Konstruktivisme dan VCT sebagai Inovasi Pendekatan Pembelajaran Afektif.Jakarta: Rajawali Pers.

Agung, A.A Gede. 2011. Pengantar Evaluasi Pendidikan. Singaraja: Universitas Pendidikan Ganesha.

Agung, A.A Gede. 2014. Metodologi Penelitian Pendidikan. Malang: Aditya Media Publishing.

Agung, A.A Gede. 2016. Statistika Dasar untuk Pendidikan.Yogyakarta: Deepublish.

Anwar, Muhammad. 2015. Filsafat Pendidikan. Jakarta: Prenadamedia Group.

Arikunto, Suharsimi. 2015. Dasar-Dasar Evaluasi Pendidikan. Jakarta: PT Bumi Aksara.

Haris Fairizah.2013. Penerapan Model Pembelajaran VCT (Value Clarification Technique) Untuk Meningkatkan Kesadaran Nilai Menghargai Jasa Pahlawan Pada Siswa Sekolah Dasar. JPGSD Volume 01 Nomor 02 Tahun 2013

Sariani Dwi. 2016. Pengaruh Model Pembelajaran Value Clarification Technique (Vct) Terhadap Sikap Sosial Dan Hasil Belajar Mata Pelajaran Pkn Pada Siswa Kelas Iv Sd. e-Journal PGSD Universitas Pendidikan Ganesha Jurusan PGSD Vol: 4 No: 1 Tahun: 2016

Sri Rejeki.2015. Penggunaan Model Pembelajaran Value Clerification Tehnique (VCT) Untuk Meningkatkan Civic Disposition Siswa Kelas V Sd N Kalasan I, Sleman. Jurnal Pendidikan Guru Sekolah Dasar Edisi 6 Tahun ke IV April 2015.

Sugiyono. 2010. Statistika untuk Penelitian. Bandung: Alvabeta.

Sugiyono. 2016. Metode Penelitian Pendidikan (Pendekatan Kuantitatif, Kualitatif, dan R\&D). Bandung: Alvabeta.

Susanto, Ahmad. 2013. Teori Belajar dan Pembelajaran di Sekolah Dasar.Jakarta: Prenada Media Group.

Taniredja, Tukiran, dkk. 2015. Model-model Pembelajaran Inovatif dan Efektif. Bandung: Alfabeta.

Widayanti, Ida Ayu Vera, dkk. 2017. "Pengaruh Model Pembelajaran Value Clarification Technique (VCT) terhadap Hasil Belajar PKN Siswa Kelas V di SD Gugus IV Kecamatan Sukasada". E-Journal PGSD Universitas Pendidikan Ganesha, Volume 5, Nomor 2. (diakses pada tanggal 23 Februari 2018)

Yusuf, A.Muri. 2015. Asesmen dan Evaluasi Pendidikan. Jakarta: Prenadamedia Group. 